\section{TWELFTH INTERNATIONAL CONGRESS OF LIMNOLOGY}

$\mathrm{T}$

HIS Congress, like the preceding ones (see Nature, 162,$623 ; 1948$ ) held under the auspices of the International Association of Limnology (President : Dr. Gunnar Alm (Sweden)), opened at Cambridge on August 20 and terminated at Windermere on August 30. The first to be held in Great Britain, it attracted nearly three hundred people belonging to about thirty-five different countries. On the first evening those taking part gathered at a reception at Trinity College, while on the last afternoon at Cambridge the Master and Fellows of Christ's College entertained them at a garden party. On the evening of August 21, Prof. D'Ancona (Padua) delivered the first Baldi Memorial Lecture, founded by his countrymen in memory of the late Prof. E. Baldi. Prof. D'Ancona, who spoke in English, took as his theme the stability of lake plankton communities, a topic to which Baldi and his co-workers made manifold contributions. On the evening of August 25, Dr. E. Windle Taylor (Great Britain) gave an account of the reservoirs of the Metropolitan Water Board; on August 22, Dr. J. W. Jones (Great Britain) showed a cinematograph film of salmon spawning, while other films relating to fisheries were shown on the evening of August 24.

Upwards of a hundred papers were read during the scientific sessions at Cambridge, but only some of them can be referred to here. Many discussed from one point of view or another topics that are momentarily in the forefront of limnological investigation. Papers dealing with temperature-relationships and circulation in lakes attracted much attention. While C. H. Mortimer described the effects of the earth's rotation on the internal wave pattern, B. Dussart (France) dealt with the influence of inflowing water and sublacustrine springs on thermal stratification and discussed heat-absorption and nocturnal radiation from the surface, a subject considered by H. Charnock from the meteorological point of view. A paper by H. Neumann (Israel) dealt with the second minimum of evaporation which occurs during the period of greatest heating in lakes of middle latitudes. E. S. Deevey (United States) and E. Gessner (Germany) reported on temperature-relationships in tropical South American lakes, and K. Vaas on those of shallow ponds in Indonesia. Various German speakers contributed papers on the classification of lake-types, while E. Teiling (Sweden) reported on phytoplankton indicators in this connexion.

Lake sediments were considered from many different angles. G. E. Hutchinson (United States) gave a highly stimulating account of investigations of the carotenoid pigments and amino-acids present in them, while E. S. Deevey emphasized the importance of palæolimnology as a tool in studying the geographical distribution of the organisms recognizable in the sediments. Sediments also entered largely into discussions on productivity. F. R. Hayes (Canada) described experiments demonstrating the role of bacteria at the mud-water interface on the uptake of radiophosphorus and suggested that artificial increase of the area of the bottom might have the same effect as addition of nutriments (fertilization). D. S. Rawson (Canada) laid emphasis on the shape of the basin as a factor influencing productivity in large lakes. E. A. Thomas (Switzerland) reported the results of monthly estimations and analyses of sedimented material, while H. Järnefelt described similar observations made in southern Finland. H. Dammas (Belgium) described the important contribution made by the phytoplankton to sediments in shallow lakes of the Congo, while J. Symoens (Belgium) gave an account of tufa deposits due to Chironomid larvæ, associated with Phormidium incrustatum. The bottom fauna was dealt with by $\mathbf{K}$. Berg (Denmark) and F. Lenz (Germany), while .J. H. Mundie (Great Britain) discussed the distribution of Chironomid midges in $\mathbf{a}$ Thames reservoir.

As regards other aspects of productivity, W. Ohle, in considering the rapid eutrophy of many North German waters, pointed out that even purified sewage effluents contribute materially towards mineral enrichment of surface waters, while a paper by G. A. Prowse (Sudan) discussed the contribution of the flora as a whole to the productivity of a water. W. Rodhe (Sweden) reported on the probable role of minute and partly heterotrophic green algæ in subarctic lakes in maintaining during winter a zooplankton of about the same magnitude as is found in summer, and G. E. Fogg discussed the importance of polypeptides excreted by algx in relation to productivity.

Among papers dealing directly with plankton, mention may be made of those of J. Rzóska (Sudan) on that of the White Nile, which attains a maximum during the accumulation of water above the dam south of Khartum; of V. Tonolli (Italy), who considered the fate of zooplankton washed into rivers from the surface waters of lakes; of W. Schmitz (Germany), on the occurrence of water-flowers in flowing waters; of J. F. Talling, on the light-relations of the phytoplankton; and of $\mathbf{M}$. Shilo (Israel), on the use of ammonium sulphate in the control of the toxin-producing phytoflagellate Prymnesium. $\mathrm{O}$. Ravera (Italy) and U. Røen (Denmark) discussed seasonal variation in reproductive rate of pelagic Copepods. R. Margalef (Spain) discussed the influence of higher temperatures on morphology of freshwater organisms. A. A. Aleem (Egypt) described the use of triphenyltetrazolium chloride in the measurement of plankton populations, while A. van der Werff (Netherlands) reported on a new method for cleaning diatoms using hydrogen peroxide and potassium permanganate.

Many speakers dealt with aspects of the distribution of freshwater organisms. S. Stankovič (Yugoslavia) considered speciation in Lake Ohrid. H. B. Hynes (Great Britain) and S. G. Segerstråle (Finland) discussed the distribution of Gammarus in Britain and Scandinavia respectively, J. Illies (Germany) emphasized the importance of Plecoptera owing to their restriction to definite temperature ranges and speeds of current, while K. H. Mann dealt with the factors determining the distribution of leeches, and A. G. Dahm (Sweden) gave an account of the recent immigration into Europe of the Planarian Dugesia tigrina. C. Kosswig (Turkey) discussed the marine element in the fish-fauna of freshwater lakes near the Sea of Marmara. Other speakers considered aspects of the introduction of fish. P. Vivier and E. Hubault discussed the causes of the lack of success in introducing Salmonidæ into French waters, E. G. Calderon dealt with the introduction of pike into Spain, J. R. Dymond gave an account of the introduction and spread of Salmo trutta and Cyprinus carpio in Canada, and D. Hey (South Africa) described the culture, especially of bream, in the final effluent from a sewage works. 
Of other papers dealing with fish, mention may be made of those of S. Runnström (Sweden), who described the damage to roe of char resulting from the winter-lowering of the water-level in an impounded lake; of H. D. Slack (Great Britain), dealing with factors affecting the survival of Coregonus eggs ; and of E. D. Le Cren with those conditioning survival of perch after hatching in Windermere.

On the botanical side A. Lundh-Almestrand discussed the distribution of diatoms in Scanian lakes in relation to their geological structure, F. Hustedt (Germany) gave an account of the influence of temperature on the diatoms of solfataras in Salvador, B. Knudsen dealt with the distribution of Tabellaria in the Lake District, while G. Lohammer (Sweden) discussed the introduction of foreign macrophytes.

On the applied side O. Jaag (Switzerland) and D. M. Newitt dealt with general aspects of pollution, F. T. K. Pentelow and J. R. H. Allan with its effects on the distribution of fish, and R. W. Butcher with organisms indicative of stages in recovery from pollution. T. Braarud (Norway) discussed pollution in the Oslo Fjord, while C. J. Rasmussen described pollution by silage juices in Denmark. H. Jakob and M. Nisbet (France) gave an account of experiments on the toxic effects of derivatives of ammonium compounds on algæ and fish, while K. Wuhrmann (Switzerland) and D. W. M. Herbert discussed the influence of various factors on the toxicity of poisons to fish. E. Hubault (France) considered toxicity in relation to molecular structure, while A. B. Wheatland dealt with the influence of traces of oxygen in bringing about absence of sulphides in polluted estuaries.

Various British workers treated of matters concerned with sewage disposal. S. Baines et al. described the correlation between the peritrichous ciliate population and the quality of the effluent from activated sludge, H. Painter discussed the factors affecting the growth of fungi in percolating filters, while T. G. Tomlinson considered means of controlling their growth. E. Weise described the use of effluents in German agriculture and W. Husmann gave an account of recent methods of effluent purification in Germany.

Other speakers dealt with water supply. E. Mercier (Switzerland) described improvements in the water of a eutrophic lake resulting from artificial subsurface aeration, A. Guelin (France) discussed the role of bacteriophage in self-purification, and $J$. Wautier (France) described experiments demonstrating the importance of the biological film in sand filters in retaining $B$. coli. A. T. Palin discussed chlorination, while L. A. Allen, dealing with a new method of estimating numbers of fæcal bacteria in a sewage effluent, referred to their rapid decrease which is not accounted for by dilution.

At the final session in Windermere, the present officers of the International Association of Limnology having indicated their desire to retire, Prof. F. E. Fritsch was elected president and Dr. T. T. Macan general secretary. During the opening session at Cambridge, Naumann Medals were awarded to Prof. Lenz (Italy) and Dr. L. Findenegg (Austria).

Visits to Wicken Fen, the Norfolk Broads, the Luton sewage disposal works, and the Water Pollution Research Laboratory at Garston were arranged during the days spent at Cambridge. The journey to Windermere was made by coach, and occupied three days, with visits to the valleys of the Wharfe and Ure,
Wensleydale, Ladybower Reservoir (Bamford), and the sewage works of Birmingham at Barston and Minnworth and of Bradford. During the two days spent at Windermere, one was devoted to inspection of the laboratory of the Freshwater Biological Association and of the experimental hatchery and fishponds at Wraymires, the other to tours in the Lake District. A small number of members visited the Rivers Avon and Test in a pre-congress excursion, while about a hundred took part in a four-days excursion into Scotland after the end of the Congress, visiting the Glasgow University Field Laboratory on Loch Lomond, the Brown Trout Research Laboratory and the Tummel-Garry hydroelectric installations at Pitlochry, and returning via Inverness, Loch Ness and Fort William to Glasgow. A small party then proceeded on a seven-days excursion in Ireland.

F. E. Fritsch

\section{A FOSSIL HUMAN MANDIBLE FROM A LEVALLOISO-MOUSTERIAN HORIZON IN CYRENAICA}

\author{
By Drs. C. B. M. McBURNEY, J. C. TREVOR and \\ L. H. WELLS
}

Department of Archæology and Anthropology, University of Cambridge, and Department of Anatomy, University of Edinburgh

TN 1947 and 1948, and again in 1951 and 1952, expeditions sponsored by the Department of Archæology and Anthropology at Cambridge visited northern Cyrenaica to study the Pleistocene geology and prehistoric archæology of the Gebel Akhdar coastline ${ }^{1}$. Since the region had been largely unexplored from this point of view, the work of the first two seasons was concentrated on establishing so far as possible the outlines of the geological and archrological sequences during the Pleistocene and their correlation. The final report on it is now in the press. The two following seasons, in 1951 and 1952, were largely devoted to the investigation of a site discovered at the end of the 1948 season-the Haua Fteah or Baker's (literally Dough-Kneader's) Hole.

\section{The Haua Fteah Site (C. B. M. McB.)}

The fossil human mandible discussed below was found at Haua Fteah in August 1952. Despite its incomplete state, the specimen is of special interest owing to the exceptionally clear evidence of geological dating and archæological associations peculiar to the site. This consists of a vertical shaft-like cavity, oval in plan and $80 \mathrm{yd}$. in minimum diameter, originally partially or wholly closed at the top by a dome-shaped roof. Apparently as a result of its situation close to the shore forming the northern margin of the limestone plateau which constitutes the Gebel Akhdar, about half this roof has been eroded away. The remaining roofed-in portion of the shaft is roughly semicircular in shape and $80 \mathrm{yd}$. in diameter ; the seaward part is open to the sky. Sediments in the seaward part are probably to a large extent subaerial in origin and would appear to have been carried under the overhang as they formed, 